\title{
Macroeconomic Determinants of Capital Flight: Evidence from the Sub-Saharan African Countries
}

\author{
"Friday Osemenshan Anetor \\ Pant-Itlintic Lniversity, Ligas, ligeriia
}

\begin{abstract}
The aim of the study was to examine the macroeconomic determinants of capital flight from the Sub-Saharan African (SSA) countries between the period 1981-2015. The study used secondary data obtained from the World Bank Development Indicators (WDI) and applied the autoregressive distributed lag (ARDL) model technique to determine the macroeconomic factors influencing capital flight from the SSA region. The results of the study showed that economic growth had a significant negative relationship with capital flight in both the long-run and shortrun. Also, the outcome of the study revealed that external debt had a significant positive relationship with capital flight in the short-run. In addition, the study noted that economic variables such as interest rate spread, inflation, and trade openness have no significant influence on capital flight in the SSA region. Overall, the study revealed that economic growth rate and external debt constitute the macroeconomic fundamentals that influence the rate of capital flight from SSA countries.

Keywords: Capital flight, economic growth rate, external debt, $A R D L$, Sub-Saharan Africa

JEL:F32, F34, F43
\end{abstract}

The capital flight in sub-Saharan African (SSA) countries has remained the front burner issue in the literature following its adverse effect on macroeconomic stability and economic growth (Osei-Assibey et al., 2018). Many scholars (e.g., Cooper and Hardt, 2000; Forgha, 2008; Grigoryev and Kosarev, 2000; Le and Rishi, 2006; Ndikumana and Boyce, 2003; Nyong, 2003; Škare and Sinkovi ć, 2013) have defined capital flight as an illegal outflow of capital which inhibits economic growth and development from the countries of origin. Capital flight, according to Onodugo et al. (2014), is different from capital export, which consists of conveyance of capital in full accordance with the law. While capital export is a normal economic phenomenon, which does not endanger the economy; capital flight presents a danger and leads to the impoverishment of the economy, worsening the possibilities of investment and prospects for further development of the economy. Capital flight can be done through illegal electronic funds transfers from private banking services, declaring of non-existing foreign debts, currency smuggling, over-invoicing of imports and under-invoicing of exports (Vukenk- 


\section{Anetor}

eng and Mukete, 2016).

The rapid rate of capital flight from the SSA region in recent decades has called for urgent attention. For example, between 1981 and 1995, capital flight from SSA totaled US\$234.7 billion following the unfavorable macroeconomic environment, weak institutions, and poor governance during the period as shown in Figure 1.

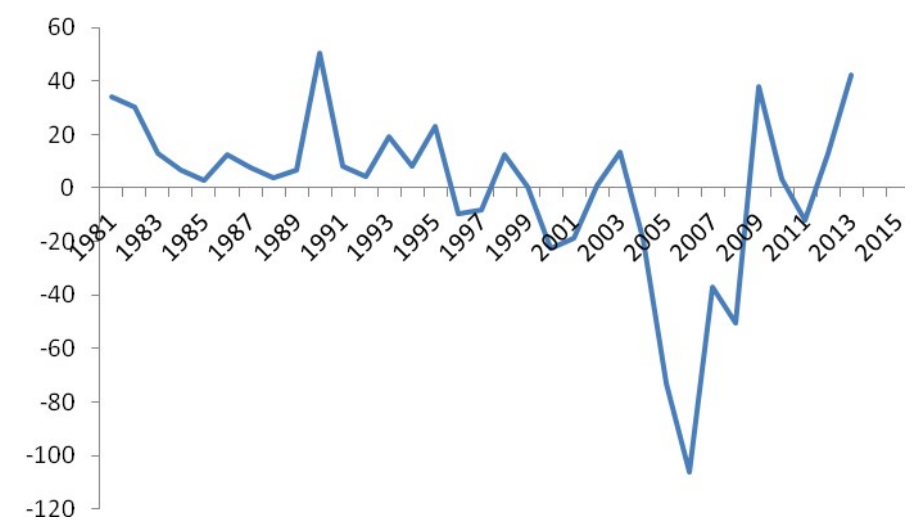

Figure 1. Trends of Capital Flight from SSA: 1981-2015 (US Billion)

However, SSA experienced a 'reversal' in capital flight in 1996 and 1997. A reversal in capital flight is a situation whereby the uses of fund exceed the sources of fund. SSA also experienced capital flight amounting to US $\$ 18.91$ billion between 1998 and 1999 but recorded a reversal of US $\$ 40.02$ billion between 2000 and 2001. SSA witnessed the highest reversal of capital flight amounting to US\$306.97 billion between 2004 and 2008 following the increased favorable macroeconomic environment, quality institutions, and good governance. However, capital flight increased rapidly in 2009 as a result of the 2008-09 financial crises. The volume of capital flight from the SSA at the tail of the financial crises in 2009 was US $\$ 36$ billion. In 2011, the region again witnessed capital flight reversal to the amount of US\$19.13 billion. The periods, 2012 all through 2015, constituted the period of a high rate of capital flight from SSA.

The high magnitude of capital flight has led to the diversion of scarce economic resources away from domestic investment and productive activities, which has resulted in poor economic performance 
International Journal of Management, Economics and Social Sciences

of SSA countries (Osei-Assibey et al., 2018; Vukenkeng and Mukete, 2016). Consequently, the literature (e.g., Collier et al., 2004; Epstein, 2005; Ndikumana and Boyce, 2011) has examined the cause of capital flight in SSA countries. However, most of the studies that examined the causes of capital flight did not specifically analyze the economic determinants of capital flight from SSA. In other word, panel studies that specifically analyzed the macroeconomic determinants of capital flight in SSA countries are sparse. Few studies that attempted to study the economic determinants of capital flight are mostly country specific (e.g., Al-Basheer et al., 2016) but not panel studies. Also, the underpinning theories explaining the causes of capital flight did not bring to bear the macroeconomic fundamentals causing capital flight. For instance, the investment diversion thesis noted that the macroeconomic and political instability in the developing economies are the causes of capital flight. It, however, failed to state the macroeconomic variables causing capital flight. In the same vein, the debt-driven thesis attributed the causes of capital flight to external debt thus, ignoring other economic factors that significantly influence capital flight from developing countries. To fill this gap, this study specifically investigates macroeconomic variables that determine capital flight from the SSA region in both the long-run and short-run. This study, therefore, contributes to the literature by unraveling the macroeconomic fundamentals influencing capital flight from the region, thus, providing a guide for policymakers and the international community in debating and formulating policies and initiatives with respect to capital flight.

The remaining parts of this study are structured as follows: the second part of this study is the literature review while the third and fourth are the theoretical framework and methodology, respectively. The fifth part presents the results of the findings. The sixth section discusses the findings and the last section features the conclusion and policy recommendations.

\section{LITERATURE REVIEW}

A strand of literature exists on the factors determining capital flight. Ljungwall and Zijian (2008) used quarterly data between the periods 1993:Q1-2003:Q4 to investigate the causes of capital flight in Chi- 


\section{Anetor}

na. Employing co-integration and innovation accounting techniques the study found that the changes in external debt significantly influenced the change in capital flight from China. Also, the study found that growth in real Gross Domestic Product (GDP) and the foreign investors' confidence rise have an inverse relationship with capital flight.

Ajilore (2010) examined the capital flight from Nigeria between the periods 1970-2004 and found that trade faking constitutes the fundamental means through which capital flight was affected in Nigeria. In the same vein, Bakare (2011) investigated the roles and the causes of capital flight in the Nigerian economy. Using the vector autoregressive (VAR) approach in determining the source of shock to capital flight from Nigeria, the study found that external debt and corruption significantly determine capital flight from Nigeria.

Employing the Ordinary Least Squares (OLS) technique, Han et al. (2012) carried out an investigation to ascertain whether there is an occurrence of capital flight from Hong Kong and to know the determinants of capital flight. The findings of the study revealed that the determinants of capital flight from Hong Kong are over-valuation of the currency, currency account deficit, and China's Open Door Policy of 1979, captured by a dummy variable.

Kipyegon (2004) investigated the factors that account for capital flight from Kenya using a time series data between the period 1971-2001. Employing the Ordinary Least Squares (OLS) technique, the study found external borrowing as the most significant factor in determining capital flight from Kenya. The outcome of the study revealed that inflation rate, real exchange rate, real economic growth, and financial development are determinants of capital flight from Kenya. As a result, the study suggests that the Kenya's government should ensure accountability and transparency in the borrowing and management of external borrowings.

Using the OLS method, Aziz et al. (2014) analyzed the determinants of capital flight from Bangladesh spanning from 1972 to 2013. The outcome of the study revealed that Foreign Direct Investment (FDI) inflows, external debt, foreign reserves constitute were the major causes of capital flight. The study also showed that other determinants of capital flight like manipulation in stock excha- 
International Journal of Management, Economics and Social Sciences

nges, under-invoicing and over-invoicing of trade settlement, leakages in the public development expenditure, illegal financial activities in the state-owned enterprises, corruption in the administration of taxes, and illegal income generated from economic crimes should be investigated.

Al-Basheer et al. (2016) employed the OLS technique to investigate the economic causes of capital flight in the Jordanian economy over the period 2000-2013. The study noted that external public debt, economic openness, taxes, and the previous capital flight significantly determined capital flight from Jordan. The study suggests that the reduction of the level of external debt and the collaboration with the international institution will go a long way in reducing the phenomenon of capital flight in Jordan.

Liew, Mansor and Puah (2016) carried out an empirical investigation on the macroeconomic causes of capital flight in the Malaysian economy between the period 1980-2010. Using the autoregressive distributed lag (ARDL) model, the study found that political risk and financial crisis positively and significantly influence capital flight in the long-run.

Employing the ARDL model, Forson, Obeng and Brafu-Insaidoo (2017) investigated the long-run and short-run determinants of capital flight in the Ghanaian economy between the period 1986-2015. The outcome of the study showed that higher domestic real interest rate in relation to foreign interest rate, good governance, financial development, real GDP growth rate, and strong property right have a significant influence in reducing capital flight in both the long-run and short-run. The result further revealed that the ratio of external debt to GDP resulted in an increase in capital flight. In addition, the study noted that lagged external debt to GDP and financial development had a negative and a positive impact on capital flight, respectively, in the short-run.

Auzairy et al. (2017) investigated the dynamic relationship between capital flight and macroeconomic fundamentals in Malaysia between 1992 and 2012. Using co-integration and vector autoregression methods of estimation, the study noted that Consumer Price Index (CPI), GDP, interest rate and exchange rate constitute the macroeconomic fundamentals determining capital flight.

Uddin, Yousuf and Islam (2017) carried an econometric analysis of the determinants of capital flight in Bangladesh between 1973 and 2013. They used OLS and noted that the major causes of cap- 


\section{Anetor}

ital flight are foreign direct investment flows, external debt, interest rate differentials, foreign reserves, and current account surplus. The study also concluded that there is a strong positive correlation between interest rate differential and capital flight and between change in external debt and capital flight.

Salandy and Henry (2018) examined the determinants of capital flight from Trinidad and Tobago between 1971 and 2011. Using the OLS and the Generalized Method of Moments (GMM) techniques of estimation, the study noted that the major causes of capital flight include the lagged external debt, lagged capital flight, external debt, GDP growth, interest rate differential, and excess liquidity.

\section{-Theoretical Framework}

This study is hinged on two main theories on capital flight i.e. the investment diversion thesis and the debt-driven thesis. The investment diversion thesis posits that due to the macroeconomic and political instability in the developing economies, some bureaucrats, unscrupulous politicians and corrupt leaders habitually siphon fund meant for the state to advance nations where there is the existence of better investment opportunities, high foreign interest rate, a wide array of financial instruments, and macroeconomic stability. As a result, the home countries suffer from an insufficient fund that debilitates the level of investment, employment opportunities, and economic growth. The adverse macroeconomic condition of the home countries will spur the home to borrow from abroad to revive the economy and this would result in external dependency and indebtedness. According to Ajayi and Khan (2000), the liquidity constraint may also lead to the depreciation of the local currency if the country is operating a floating exchange rate system. An attempt by the authorities to defend the exchange rate at this time would result in depletion of international reserves.

The debt-driven thesis, on the other hand, asserts that capital flees a country in response to economic circumstances attributable to external debt (Boyce, 1992). According to this theory, the external debt may have an adverse effect on the exchange rate in the long-run if the debt is incurred for purposes that would not generate adequate foreign exchange for repayment. For instance, when external debt is due for repayment, there would be an increased demand for foreign currency and this 
would depress the value of the local currency. The response of a rational asset holder in this situation is to dollarize when the local currency is artificially inflated in the expectation of its eventual decline. Since, the dollarization of the local currency would further amount to increased demand for foreign exchange, this would eventually result in depreciation of the local currency. In the same vein, external debt may also preempt favorable investment opportunities or reduce domestic interest rate thereby crowding out domestic capital and pushing it abroad. This theory, therefore, presupposes that capital flight, which is driven by external debt, can result in exchange rate devaluation, fiscal crisis, and the propensity of the crowding out of domestic capital and expropriation of assets to pay for the debt (Ifedayo and Olawale, 2015; Onodugo et al., 2014).

Based on the literature review the following hypotheses are proposed:

$\mathrm{H}_{01}$ : Interest rate spread has no significant impact on capital flight in sub-Saharan African countries

$\mathrm{H}_{02}$ : Trade openness has no significant impact on capital flight in sub-Saharan African countries.

$\mathrm{H}_{03}$ : Inflation has no significant impact on capital flight in sub-Saharan African Countries.

$\mathrm{H}_{04}$ : Economic growth rate has no significant impact on capital flight in sub-Saharan African countries.

$\mathrm{H}_{05}$ : External debt has no significant impact on capital flight in sub-Saharan African countries.

\section{METHODOLOGY}

\section{-Model Specification}

Following the investment diversion thesis and debt-driven thesis the functional model of this study can be expressed as:

$$
C A F=f\left(E G R, E X D, I N F, I R S_{\imath} T O P\right)
$$

The econometric model from equation (1) can thus be expressed as follows:

$$
C A F_{t}=\beta_{0+} \beta_{1} E G R_{t}+\beta_{2} E X D_{t}+\beta_{3} I N F_{t}+\beta_{4} I R S_{t}+\beta_{5} T O P_{t}+\mu_{t}
$$

Where: 


\title{
Anetor
}

\author{
$\mathrm{CAF}_{\mathrm{t}}=$ Capital Flight \\ $\mathrm{EGR}_{\mathrm{t}}=$ Annual Growth Rate of GDP \\ $\mathrm{EXD}_{\mathrm{t}}=$ External Debt \\ $\mathrm{INF}_{\mathrm{t}}=$ Inflation Rate \\ IRS $_{\mathrm{t}}=$ Interest Rate Spread \\ TOP - Trade Openness \\ $\mu_{\mathrm{t}}-$ Error Term
}

\section{-Source of Data}

The study used aggregate data for the Sub-Saharan African countries from 1981-2015. Data on external debt (EXD), current account deficit (CAD), change in foreign exchange reserve (FER), and direct foreign investment (NFDI) were obtained from the IMF World Economic Outlook (WEO) database. Data on interest rate spread (IRS) and economic growth rate (EGR) were sourced from the World Development Indicator (WDI). Trade openness (TOP) was measured as the percentage ratio of the sum of exports and import to the gross domestic product. Capital flight (CAF) was measured using the residual method. The rationale for choosing the residual method was because it is considered as the most widely used method of measuring capital flight (Al-Basheer et al., 2016; Aziz et al., 2014; Kipyegon, 2004; Lensink et al., 2000; Ljungwall and Zijian, 2008). The residual method computes capital flight by comparing the sources of funds with the uses of fund (Claessens et al., 1993). Sources of funds, according to Claessens et al. (1993), include all net official flows (net increase in external debts of the public sector) and the net flow of foreign direct investment (FDI) while uses of funds include the current account deficit and additions to reserves. Thus, capital fight was measured as: $\triangle E X D+N F D I-(C A D+\triangle F E R)$.

\section{-Autoregressive Distribution Lag (ARDL) Model}

This study employed the Autoregressive Distribution Lag (ARDL) approach to estimate the long-run and short-run causes of capital flight. ARDL was employed because it allows for the combination of 
variable integrated of the order of $\mathrm{I}(0)$ and I(1). Also, ARDL provides estimates of the corresponding error correction model (Ogbechie and Anetor, 2016). The ARDL model of capital flight can be expressed as:

$$
\begin{aligned}
\Delta C A F_{t}=\beta_{0}+ & \omega_{1} C A F_{t i}+\omega_{2} I R S_{t_{i} i}+\omega_{3} T O P_{t i}+\omega_{4} I N F_{t i}+\omega_{5} E G R_{t i}+\omega_{6} E X D_{t i} \\
& +\sum_{i=1}^{n} \theta_{i} \Delta C A F_{t-i}+\sum_{i=1}^{n} \alpha_{i} \Delta I R S_{t-i}+\sum_{i=1}^{n} \delta_{i} \Delta T O P_{t-i}+\sum_{i=1}^{n} \varphi_{i} \Delta I N F_{t-i} \\
& +\sum_{i=1}^{n} \emptyset_{i} \Delta E G R_{t-i}+\sum_{i=1}^{n} \lambda_{i} \Delta E X D_{t-i} \\
& +\mu_{t}
\end{aligned}
$$

Where $\beta_{0}$ is a drift component, $\Delta$ connotes the first difference of the variables, $n$ is the lag lengths and the $\mu_{t}$ is error term. The coefficient of the lagged variables $\left(\omega_{1}\right.$ to $\left.\omega_{6}\right)$ are the long-run multipliers while $\theta_{i}, \alpha_{i}, \delta_{i}, \varphi_{i}, \emptyset_{i}$, and $\lambda_{i}$, represent the short-run coefficients.

In ARDL bound testing, the $f$-Statistic was used to test the existence of a long-run relationship. The $f$-statistic was compared with the critical values at 5 percent to ascertain the presence or absence of a long-run relationship. If the $f$-statistic exceeds the upper bound value of the critical value, it can be said that there is a long-run relationship between the variables and if it is lesser than the lower bound value, then there is no evidence of a long-run relationship. In case the $f$-statistic falls between the lower and upper bound values, the result is said to be inconclusive.

\section{-Unit Root Test}

The study employed the Augmented Dickey-Fuller (ADF) and the Phillip-Peron (PP) test to test for stationarity. The advantage of using ADF is that it is considered as the simplest procedure for testing stationarity and it is also appropriate for a large and complex set of data. The ADF test estimation procedure is expressed as follows:

$$
\Delta Y_{t}=\lambda+\delta t+\beta Y_{t-1}+\varphi_{i} \sum_{i=0}^{n} \Delta Y_{t-1}+\mu_{t}
$$

Where $\Delta Y_{t}$ connotes the lag difference of the variable of interest, $\lambda$ is the constant term, $n$ is the

number of lag, $t$ is the time trend, and $\mu_{t}$ is the error term. The study also applied the Phillips-Perron 


\section{Anetor}

(PP) test to test for stationarity because it is commonly used as an alternative to the ADF test

(Fedorová, 2016). The advantage of the PP tests over the ADF tests is that PP tests are robust to general forms of heteroskedasticity in the error term. Also, the user does not have to specify a lag length. The PP regression test is expressed as:

$$
\Delta y_{t}=\beta^{\prime} D_{t}\left|\pi y_{t-1}\right| \mu_{t}
$$

Where $\mu_{t}$ is $\mathrm{I}(0)$ and may be heteroskedastic. The null hypothesis is $\rho=0$ against the alternative that $\rho \neq 0$.

\section{RESULTS}

Table 1 shows the results of the Augmented Dickey-Fuller and the Philips-Perron unit root tests. The outcome of the unit root tests indicates that the variables are stationary at level and first differences. As a result, the autoregressive distributed lag (ARDL) technique of estimation becomes suitable for the study.

\begin{tabular}{|c|c|c|c|c|c|c|}
\hline Variable & $\begin{array}{c}\text { Augmented } \\
\text { Dickey- } \\
\text { Fuller } \\
\end{array}$ & & $\begin{array}{c}\text { Order of } \\
\text { Integration }\end{array}$ & $\begin{array}{l}\text { Philips- } \\
\text { Perron }\end{array}$ & & $\begin{array}{c}\text { Order of } \\
\text { Integration }\end{array}$ \\
\hline & With & With Trend and & & With & With & \\
\hline & Constant & Constant & & Constant & $\begin{array}{l}\text { Trend and } \\
\text { Constant }\end{array}$ & \\
\hline$C A F$ & $-6.49 * * *$ & $-6.52 * * *$ & $\mathrm{I}(1)$ & $-8.72 * * *$ & $-12.28 * * *$ & $\mathrm{I}(1)$ \\
\hline$I R S$ & $-4.05 * * *$ & $-4.24 * * *$ & $\mathrm{I}(1)$ & $-4.20 * * *$ & $-4.28 * *$ & $\mathrm{I}(1)$ \\
\hline TOP & $-6.47 * * *$ & $-6.51 * * *$ & $\mathrm{I}(1)$ & $-6.66 * * *$ & $-6.98 * * *$ & $\mathrm{I}(1)$ \\
\hline$I N F$ & $-3.22 * *$ & $-4.01 * *$ & $\mathrm{I}(0)$ & $-3.18 * *$ & $-4.01 * *$ & $\mathrm{I}(0)$ \\
\hline$E G R$ & $-2.89 *$ & $-3.58 * *$ & $\mathrm{I}(0)$ & $-2.84^{*}$ & $-3.58 * *$ & $\mathrm{I}(0)$ \\
\hline$E X D$ & $-4.10 * * *$ & $-4.23 * *$ & $\mathrm{I}(1)$ & $-4.09 * * *$ & $-4.23 * *$ & $\mathrm{I}(1)$ \\
\hline
\end{tabular}

Source: Authors' Computation using EViews 9

Table 1. Unit Root Tests

\section{-ARDL Bound Test for Co-Integration}

The results of the ARDL bound test is shown below. The outcome of the test indicates that the $f$-statistics is equal to 7.17 and it is greater than the upper bound critical values at 1 percent, 5 percent, and 10 percent (See Table 2). Hence, the null hypothesis of no co-integration (i.e. $H_{0}: \omega_{1}=\omega_{2}=\omega_{3}=\omega_{4}=\omega_{5}=\omega_{6}=\omega_{7}=\omega_{8}=\omega_{9}=0$ ) is rejected while the alternate 
hypothesis (i.e. $H_{1}: \omega_{1} \neq \omega_{2} \neq \omega_{3} \neq \omega_{4} \neq \omega_{5} \neq \omega_{6} \neq \omega_{7} \neq \omega_{8} \neq \omega_{9} \neq 0$ ) of the presence of co-integration cannot be rejected. This connotes that a long-run relationship exists between the variables.

\begin{tabular}{ccccc}
\hline K & $\boldsymbol{f}$-Statistics & Critical Value & Lower Bound Value & Upper Bound Value \\
\hline \multirow{2}{*}{5} & 7.17 & $1 \%$ & 3.41 & 4.68 \\
& & & & \\
& & $5 \%$ & 2.62 & 3.79 \\
& $10 \%$ & 2.26 & 3.35 \\
\hline
\end{tabular}

Source: Authors' Computation using EViews 9

Table 2. ARDL Bound Test

Having established the existence of a long-run relationship, the study also proceeds to determine the significance of each of the variables in determining capital flight (CAF) in the long-run and shortrun. The estimated results in the long-run and short-run are presented in Table 3 and Table 4 respectively.

Table 3 shows that the coefficient of economic growth rate (EGR) is negative and significant. This suggests that the rate of economic growth has a significant impact on capital flight. As a result, the null hypothesis $\left(\mathrm{H}_{04}\right)$, which states that the economic growth rate has no significant impact on capital flight, is rejected. This result is consistent with the empirical studies by Forson et al. (2017), Kipyegon (2004), Ljungwall and Zijian (2008) and, Salandy and Henry (2018). The result also found that trade openness has a negative and insignificant relation with capital flight. Therefore, the null hypothesis $\left(\mathrm{H}_{02}\right)$ that trade openness does not have a significant impact on capital flight cannot be rejected. This outcome is, however, contrary to the findings of Al-basheer et al. (2016) and Han (2011). The coefficient of inflation is found to be positive but insignificant in the long-run. This indicates that inflation does not significantly affect capital flight; hence, the null hypothesis $\left(\mathrm{H}_{03}\right)$ cannot be rejected. This outcome does not support the findings of Auzairy et al. (2017) and Kipyegon (2004). Further, the study found that the relationship between external debt and capital flight was positive but insignificant; hence, the null hypotheses $\left(\mathrm{H}_{05}\right)$ cannot be rejected. Finally, the study noted that the coefficient of 


\section{Anetor}

interest rate spread rate is positive but insignificant; hence, does not cause capital flight. As a result, the null hypothesis $\left(\mathrm{H}_{01}\right)$ that interest rate spread does not cause capital flight cannot be rejected.

\begin{tabular}{ccccc}
\hline Variable & Coefficient & Std. Error & $\boldsymbol{t}$-Statistic & Prob. \\
\hline$C$ & -96.19 & 65.28 & -1.47 & 0.15 \\
$I R S$ & 2.13 & 2.05 & 1.03 & 0.31 \\
$T O P$ & -0.18 & 1.57 & -0.11 & 0.90 \\
$I N F$ & 0.04 & 1.07 & 0.03 & 0.96 \\
$E G R$ & -8.89 & 2.60 & -3.41 & 0.002 \\
$E X D$ & 19.81 & 15.67 & 1.26 & 0.21 \\
\hline Dependent Variable $\triangle C A F$ & \multicolumn{5}{|}{ Source: Authors' Computation using EViews 9 }
\end{tabular}

Table 3. ARDL Estimated Long-Run Coefficients

Table 4 represents the short-run estimates. The result noted that the coefficient of interest rate is negative and significant suggesting that economic growth rate determines capital flight in the shortrun; hence, the null hypothesis $\left(\mathrm{H}_{04}\right)$ is rejected. This result lends credence to the studies of Forson et al. (2017), Kipyegon (2004), Ljungwall and Zijian (2008), and Salandy and Henry (2018). It is also noted that the coefficient of external debt is positive and significant thus, indicating that external debt influences capital flight in the short-run. Hence, the null hypothesis, which states that external debt does not have a significant impact on capital flight, is rejected. This result is consistent with the studies by Al-basheer et al. (2016), Aziz et al. (2014), Bakare (2011), Kipyegon (2004), Ljungwall and Zijian (2008), Salandy and Henry (2018), and Uddin et al. (2017). Further, the result indicates that the coefficient of inflation is positive but is insignificant. This implies that inflation does not cause capital flight; hence, the null hypothesis $\left(\mathrm{H}_{03}\right)$, which specifies that inflation does not have a significant impact on capital flight, cannot be rejected. This, however, is not consistent with the empirical findings of Auzairy et al. (2017) and Kipyegon (2004). The coefficient of trade openness is negative and significant thus indicating that trade openness does not influence capital flight. As a result, the null hypothesis $\left(\mathrm{H}_{02}\right)$, which states that trade openness does not have a significant impact on capital flight cannot be rejected. Finally, the coefficient of interest rate spread is positive but insignificant; hence, the null hypothesis $\left(\mathrm{H}_{01}\right)$, which expresses that interest rate spread does not have a significant impact on capital flight cannot be rejected. 
International Journal of Management, Economics and Social Sciences

The error correction term (ECT) explains how quickly or slowly in which the relationship is restored get back to its equilibrium path. The coefficient of the ECT $(-1)$ is expected to be negative and must be statistically significant. A highly significant ECT $(-1)$ provides proof of the existence of a stable long-run relationship. Table 4 indicates that the coefficient of the ECT $(-1)$ is equal to -0.80 and is significant. This suggests that deviation from the long-run path is corrected by 80 percent over the following year. This result presupposes that the adjustment occurs very quickly. The $R$-square connotes that the explanatory variables account for 81 percent variation in capital flight. The $f$ statistic, which indicates the overall significance level of the estimate, showed that the overall estimate is significant as the $p$-value is less than 5 percent. The Durbin Watson (DW) statistic of 1.75 suggests the absence of first-order serial autocorrelation.

\begin{tabular}{ccccc}
\hline Variable & Coefficient & Std. Error & t-Statistic & Prob. \\
\hline$\triangle I R S$ & 1.71 & 1.80 & 0.95 & 0.35 \\
$\triangle T O P$ & -2.00 & 1.11 & -1.78 & 0.08 \\
$A I N F$ & 0.03 & 0.86 & 0.04 & 0.96 \\
$\triangle E G R$ & -3.29 & 1.48 & -2.21 & 0.03 \\
$\triangle E X D$ & 203.95 & 41.33 & 4.93 & 0.0001 \\
$E C T(-1)$ & -0.80 & 0.16 & -4.97 & 0.0001 \\
R-squared & 0.81 & & & 0.000006 \\
F-statistic & 10.40 & & & \\
DW-statistic & 1.75 & \multicolumn{5}{|}{ Source: Authors' Computation using EViews 9}
\end{tabular}

Table 4. ARDL Estimated Sort-Run Coefficients

Table 5 shows the diagnostic test result of the ARDL estimates for both the long-run and short-run. The aim was to test if the underlying ARDL Eq. (3) fits very well and the model is globally significant. The outcome of the diagnostic tests indicated that the regression model passed all diagnostic tests against serial correlation (Durbin Watson test and Breusch-Godfrey test), heteroskedasticity (BreuschPagan-Godfrey heteroskedasticity test), and normality of errors (Jarque-Bera test).

Figure 2 depicts the cumulative sum of recursive residuals (CUSUM). The aim of the test was to determine whether the long-run and the short-run dynamics estimates are stable. The results show that the coefficients are stable because the plots of the CUSUM statistic fall inside the critical bands of 


\section{Anetor}

\begin{tabular}{ccc}
\hline & $\chi^{2}$ Statistics & Probability \\
\hline Breusch-Godfrey Serial Correlation LM Test & 0.63 & 0.53 \\
Breusch-Pagan-Godfrey Heteroskedasticity Test & 1.03 & 0.44 \\
Jarque-Bera test & 0.97 & 0.61 \\
\hline
\end{tabular}

Source: Authors' Computation using EViews 9

\section{Table 5. Coefficients Diagnostic Test Results}

Figure 2 depicts the cumulative sum of recursive residuals (CUSUM). The aim of the test was to determine whether the long-run and the short-run dynamics estimates are stable. The results show that the coefficients are stable because the plots of the CUSUM statistic fall inside the critical bands of the 5 percent confidence interval of parameter stability.

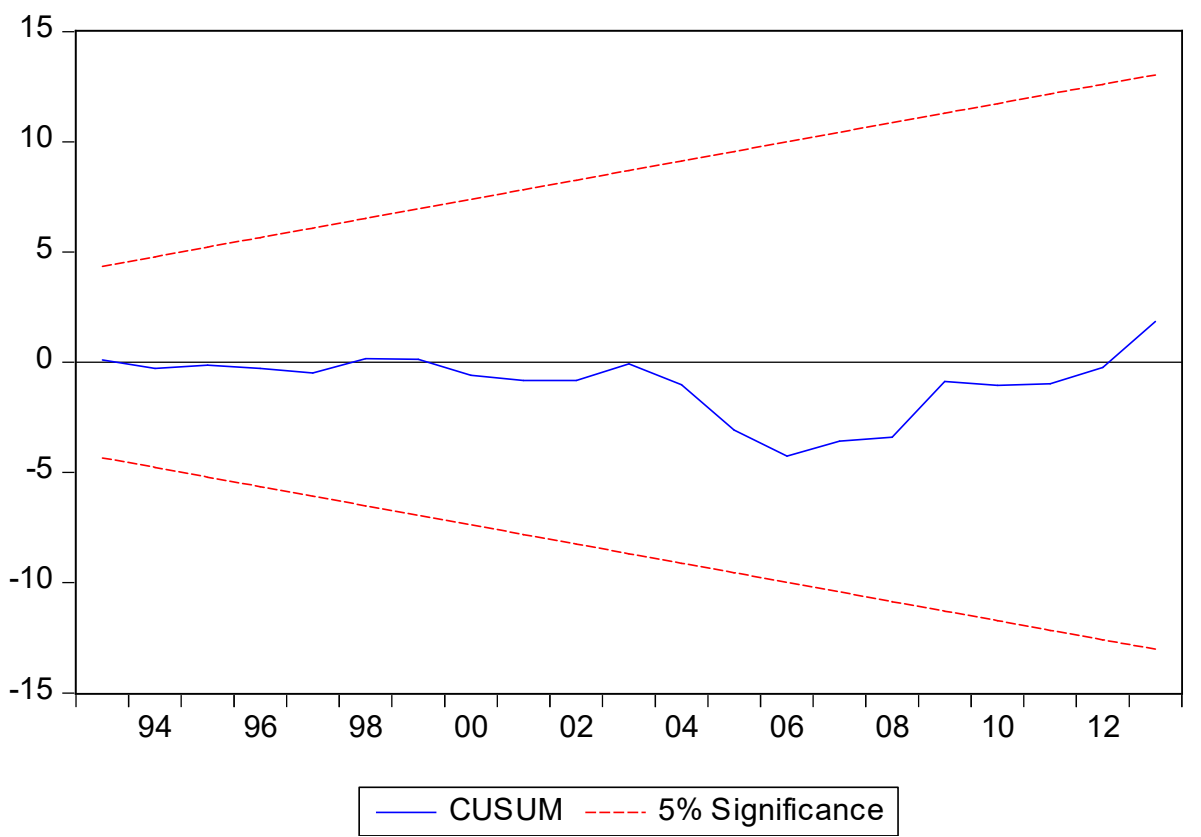

Figure 2. The Cumulative Sum of Recursive Residuals (CUSUM)

\section{DISCUSSION}

This study filled an important gap in the literature on capital flight by unfolding the macroeconomic fundamentals that cause capital flight in the SSA countries in both the long-run and short-run. The study noted that the rate of economic growth has a significant impact on capital flight in the long-run 
International Journal of Management, Economics and Social Sciences

and the relationship is an inverse relationship. It presupposes that a 10 percent increase in economic growth rate would result in 88.9 percent fall in capital flight and vice versa. The rationale for this result is that good economic performance gives the citizenry the confident and incentive to invest their resource in the domestic economy as they are confident on adequate return on investment and safety of their funds. In the same vein, foreign investors would want to reinvest their profit into the host economy as they are optimistic about getting returns on investment. This lends credence to the investment diversion thesis, which asserts that the existence of economic growth and macroeconomic stability encourage investment of capital by both citizens and foreigners while poor economic performance deters the investment of capital in the host economy.

Similarly, the results also indicate that a negative relationship exists between economic growth and capital flight and it is statistically significant in the short-run. Unlike the long-run, the study noted that a 10 percent increase in economic growth would lead to 32.9 percent fall in capital flight.

Also, the results connote that external debt has a positive relationship with capital flight and it is statistically significant. This suggests that external debt causes capital flight. The economic rationale for this outcome lies in the fact that the rapid growth of external debt in SSA over the years has detrimental effects on investment and growth. An attempt to service the built-up debt has resulted in the drain of foreign exchange resources and worsened the rate of capital flight. This lends credence to the debt-driven thesis, which noted that capital flight is attributable to external debt (Boyce, 1992).

\section{CONCLUSION}

The study examined the macroeconomic causes of capital flight from SSA countries between the periods 1981-2015. Employing ARDL, the study shows that there exists a long-run relationship between the variables. The study also noted that there is a negative relationship between economic growth and capital flight and it is statistically significant. This suggests that the rate of economic growth has a significant impact in determining the rate of capital flight from the sub-Saharan Africa countries in the long-run and short-run, thus supporting the notion of the investment diversion thesis that emphasized that macroeconomic stability plays a significant role in influencing capital flight from 


\begin{abstract}
Anetor
developing countries. The justification for this result is that good economic performance gives the citizenry the confidence and incentive to invest their resources in the domestic economy as they are confident on adequate return on investment and safety of their fund. Similarly, foreign investors would want to reinvest their profit in the host economy as they are optimistic of getting returns on investment. The study also found that interest rate spread, inflation, trade openness and external debt have no causal effect on capital flight in the long-run.

The study further noted that there is a negative relationship between trade openness and capital flight in the short-run but it is not statistically significant. The sign of the coefficient is not consistent with financial and economic theories, which concluded that there is an existence of a positive relationship between trade openness and capital flight. The explanation for this is that most open economies are least vulnerable to capital flight because transparency and openness help to improve investors' confidence in the long-term prospect of the economy. Also, the outcome of the study revealed that external debt has a positive relationship with capital flight and it is statistically significant in the short-run, thus lending credence to the debt-driven thesis, which noted that the main determinant of capital flight from developing countries is external debt. This result suggests that when capital enters a nation in the form of external borrowing, it simultaneously slips out of the country in the form of private capital flight as most external debt is being employed as a transfer mechanism for capital flight. The outcome of the study also shows that other macroeconomic variables such as interest rate spread and inflation are not statistically significant; hence, they do not influence capital flight in the region.
\end{abstract}

\title{
IMPLICATIONS
}

The findings of this study lend credence to the existing theory on capital flight. However, contrary to the existing theory, debt-driven thesis, which attributed the key causes of capital flight to external debt; the finding of this study has, however, unfolded other notable causes of capital flight. The study notes that economic growth rate is major cause of capital flight in SSA countries thus, contributing to the existing theories on capital flight. Since, external debt and economic growth rate have been noted 
as the fundamental causes of capital flight, it is, therefore, important for policymakers in SSA countries to initiate and implement policies that will propel economic growth. In addition, they should endeavor to shed the burden of external debt that has been built up over the years to reduce the rapid rate of capital flight.

\section{POLICY RECOMMENDATIONS}

In the light of the findings of the study, it is recommended that policymakers in SSA countries should formulate reforms geared towards reducing the stock of external debt and promoting steady economic growth rate in a bid to reducing the high rate of capital flight from the region. It is also important that capital inflows, in the form of external debt, should be well monitored and used judiciously on productive investment in order to avoid being siphoned by corrupt government officials. The policymakers in the region can also reduce the rate of capital flight by creating a suitable and macroeconomic environment that gets rid of domestic macroeconomic policy errors such as fiscal deficit and financial repression.

\section{LIMITATIONS AND FUTURE DIRECTIONS}

The study focused on economic factors causing capital flight from developing countries and ignored the socio-political factors that could possibly influence the rate of capital flight from SSA countries. It is, therefore, pertinent for future studies to examine noneconomic factors that could cause capital flight from the SSA region as this will guide policymakers in formulating policies pertaining to capital flight.

\section{REFERENCES}

Ajayi, S. I. \& Khan, M. S. (Eds.). (2000). External debt and capital flight in sub-Saharan Africa. International Monetary Fund. Provide complete ref.

Ajilore, T.O. (2010). An economic analysis of capital flight from Nigeria. International Journal of Economics and Finance, 2(4): 89-101.

Al-basheer, A.B., Al-Fawwaz, T.M. \& Alawneh, A.M. (2016). Economic determinants of capital flight in Jordan: An empirical study. European Scientific Journal, 12(4): 322-334.

Auzairy, N.A., Fun, C.S.F.S., Ching, T.L., Li, S.B. \& Fung, C. S. F. S. (2017). Dynamic relationships of capital flight and macroeconomic fundamentals in Malaysia. Geografia-Malaysian Journal of Society and Space, 12(2): 206-211

Aziz, M.S.I., Khayyam, M.O. \& Uddin, M.M. (2014). Determinants of capital flight in Bangladesh: an econometric estimation. Developing Country Studies, 4(25): 121-134.

Bakare, A. S. (2011). The determinants and roles of capital flight in the growth process of Nigerian economy: Vector autoregressive model approach. British Journal of Management and Economics, 1(2): 100-113.

Boyce, J. K. (1992). The revolving door? External debt and capital flight: A Philippine case study. World Development, 20(3): 335-349. 


\section{Anetor}

Claessens, S., Naude, D. \& Mundial, B. (1993). Recent estimates of capital flight (p. 1186). Washington, DC: World Bank.

Collier, P., Hoeffler, A. \& Pattillo, C. (2004). Africa's exodus: Capital flight and the brain drain as portfolio decisions. Journal of African Economies, 13(suppl_2): ii15-ii54.

Cooper, W.H. \& Hardt, J.P. (2000). Russian capital flight, economic reforms, and US interests: An analysis. Congressional Research Service, Library of Congress.

Epstein, G.A. (Ed.). (2005). Capital flight and capital controls in developing countries. Northampton: Edward Elgar Publishing.

Fedorová, D. (2016). Selection of unit root test on the basis of length of the time series and value of AR (1) parameter. Statistika, 96(3): 47-64.

Forgha, N.G. (2008). Capital flight, measurability and economic growth in Cameroon: An econometric investigation. International Review of Business Research Papers, 4(2): 74-90.

Forson, R., Obeng, K.C. \& Brafu-Insaidoo, W. (2017). Determinants of capital flight in Ghana. Journal of Business and Enterprises Development, 7, 151-180

Han, Y., Gan, C., Hu, B. \& Li, Z. (2012). Hong Kong capital flight: Determinants and features. Investment Management and Financial Innovations, 9(3): 33-46.

Ifedayo, O.M. \& Olawale, O. (2015). Impacts of capital flight on economic growth In Nigeria. International Journal for Innovation Education and Research, 3(8): 10-46.

Kipyegon, L. (2014). Determinants of capital flight from Kenya. K.U (Doctoral dissertation).

Grigoryev L. \& Kosarev A. (2000) Capital Flight: scale and nature. Paper presented at the conference on "Investment Climate and Russia's Economic Strategy, Moscow, April 2000.

Le, Q.V. \& Rishi, M. (2006). Corruption and capital flight: An empirical assessment. International Economic Journal, 20(4): 523-540.

Lensink, R., Hermes, N. \& Murinde, V. (2000). Capital flight and political risk. Journal of international Money and Finance, 19(1): 73-92

Liew, S. L., Mansor, S. A. \& Puah, C. H. (2016). Macroeconomic determinants of capital flight: An empirical study in Malaysia. International Business Management, 10(13): 2526-2534.

Ljungwall, C. \& Zijian, W.A. (2008). Why is capital flowing out of China?. China Economic Review, 19(3): 359-372.

Ndikumana, L. \& Boyce, J. K. (2003). Public debts and private assets: explaining capital flight from Sub-Saharan African countries. World Development, 31(1): 107-130.

Ndikumana, L. \& Boyce, J. K. (2011). Capital flight from sub-Saharan Africa: linkages with external borrowing and policy options. International Review of Applied Economics, 25(2): 149-170.

Nyong, M. O. (2003). Capital flight and economic growth in four African countries. In Nigeria, Cote D'ivoire, Morroco and Ghana, DMO Monthly Seminar Series (No. 2).

Ogbechie, C. \& Anetor, F. O. (2016). Determinants of capital flows into Nigeria: An autoregressive-distributed lag (ARDL) approach. Journal of Economic and Trade, 1(1): 38-50.

Onodugo, V. A., Kalu, I. E., Anowor, O. F. \& Ukweni, N. O. (2014). Is capital flight healthy for Nigerian economic growth? An econometric investigation. Journal of Empirical Economics, 3(1): 10-24.

Osei-Assibey, E., Domfeh, K. O. \& Danquah, M. (2018). Corruption, institutions and capital flight: evidence from Sub-Saharan Africa. Journal of Economic Studies, 45(1): 59-76.

Salandy, M. \& Henry, L. (2018). Determinants of capital flight from beautiful places: the case of small open economy of Trinidad and Tobago. The Journal of Developing Areas, 52(4): 85-97.

Škare, M. \& Sinković, D. (2013). The role of equipment investments in economic growth: a cointegration analysis. International Journal of Economic Policy in Emerging Economies, 6(1): 29-46.

Uddin, M. J., Yousuf, M. \& Islam, R. (2017). Capital flight affecting determinants in Bangladesh: an econometric estimation. International Journal of Economics, Commerce, and Management, 5(8): 223-248.

Vukenkeng, A. W. \& Mukete, E. M. (2016). Capital flight and economic development: The experience of Cameroon. Economics, 5(5): 64-72. 